\title{
有限要素により任意の断面形状をした棒中の 弾性波を解析する手法
}

FINITE ELEMENT TECHNIQUE FOR THE ANALYSIS OF ELASTIC WAVES IN PRISMATIC BARS OF ARBITRARY CROSS SECTION

\author{
秋田宏* \\ By Hiroshi AKITA
}

\section{1.まえがき}

応力波解新の手法汹広く衝撃, 地震波, さらには水理 学的波動, 音波, 電磁波などの問題に応用できるものと 考えられる. 本稿は, もっとも基本的な例である均質で 弹性的な無限に長い棒中の応力波を, 有限要素を用いて 解析する手法について述べるものである.

無限に長い棒中の弾性波に関しては, Pochhammer と Chree が円形断面についての厳密解省導き1), Lamb が 無限板についての厳密解を求めた ${ }^{2)}$. ここで無限板は棒 ではないが，縦波 (Longitudinal wave) を扱ら限りは 無限長円形断面棒と数学的に相似である. すなわら, 進 行方向に sine 波動を仮定して運動方程式を変数分離す ると, いずれの場合も進行方向に垂直な 1 変数の常微分 方程式が得られ，境界条件を満足する解がそれぞれよく 知られた，三角関数と双曲線関数，0階と 1 階の Bessel 関数で表わされる ${ }^{3)}$.

ところが，昱方形断面棒となると変数分離した後も 2 変数の偏微分方程式であり，2組の面における境界条件 を同時に満足寸る解は一般には求められない. Mindlin らは三角関数を用いて特別な波長に対応する解を求めた が，同時に一般的な解が簡単な関数の有限項では表わし えないことを示しだ).したがって,その後の研究は各種 の近似解法に向けられ, Legendre の多項式を用いた Medick の 1 次元化理論 ${ }^{5)}$, べき関数を用いた Nigroの 変分法 ${ }^{6}$, Bessel 関数を用いた Fraser のコロケーショ ン法などがある7). Fraser らは，さらに同法により三角 形断面に対する近似解も求めている ${ }^{8)}$.

さて, 変数分離によって 2 次元問題に帰着するのであ れば, 半解析的有限要素法 ${ }^{9)}$ と類似の考え方により任意 の断面形状についての数值解が得られるはずである. 事 実 Aalami がそのような手法を提案し ${ }^{10)}$, 正方形断面

* 正会員 工修 東北工業大学助教授 工学部土木工学科
と円形断面に適用した例を示している．著者は Aalami とは独立に同じ手法を研究してきたが111,12)，基本式の誘 導過程, 解析の対象が異なり ${ }^{13)}$ ，また彼の結論に対して 補足すべきことがらも見い出している(14),15). したがっ て，それらを比較しながら，彼の論文では触れていない ことがら, 特に 2 次要素 ${ }^{16)}$ にるる解析例を中心に述べた W.

\section{2. 運動方程式の 2 次元化}

この節では，3次元の波動現象が変数分離によって実 質的に 2 次元問題に帰着する過程を説明する。これは Aalami が変分原理を用いて手際よく導いたことを，有 限要素法の䒠際的な概念を用いて解りやすく示したもの にほかならない。

棒の軸を $x$ 軸とするデカルト座標をとり, 変位の各成 分を次のように仮定する.

$$
\left.\begin{array}{rl}
u & =U(y, z) e^{i(\omega t-\kappa x)} \\
v & =i V(y, z) e^{i(\omega t-\kappa x)} \\
w & =i W(y, z) e^{i(\omega t-\kappa x)}
\end{array}\right\}
$$

ただし， $u, v, w$ はそれぞれ $x, y, z$ 方向の変位成分, $i$ は虚数単位, $U, V, W$ は $y, z$ のみの関数で未知のも の, $\omega$ は角振動数, $t$ は時間, $\kappa$ は波数, $e$ は自然対数 の底である. 変位成分 $v, w$ に対して $\pi / 2$ の位相差を考 慮した理由について, Aalami や Nigro の論文では触 れていないが，本稿では 付録 $\mathbf{A}$ に簡単に示す.

図一1 のように， $x$ 軸に垂直で等間隔な断面 I, II, III

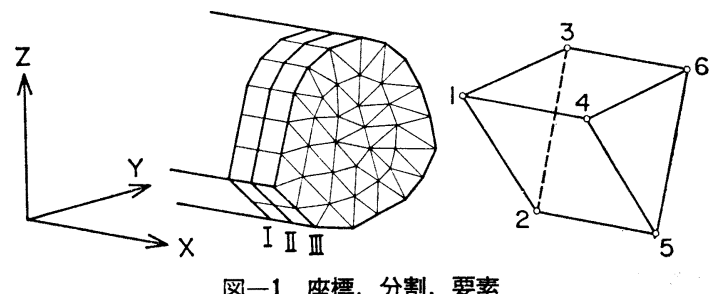


を考え，これらの面にはさまれている棒の部分を三角柱 要素により分割する. 簡単のため 1 次要素 ${ }^{16)}$ で考える と, 1 つの要素の節点数は 6 であるから要素の節点变位 ベクトルも要素の節点カベクトルも 18 成分となる.

いま面上の各節点に対して運動方程式を導くものと する. まず II, III 断面間の要素に着目すると, 要素の節 点変位ベクトルは式 (1) から次のようになる.

$$
\left\{\begin{array}{r}
u_{1} \\
i u_{2} \\
i u_{3} \\
u_{4} \\
\vdots \\
i u_{9} \\
(a-b i) u_{1} \\
i(a-b i) u_{2} \\
i(a-b i) u_{3} \\
(a-b i) u_{4} \\
\vdots \\
i(a-b i) u_{9}
\end{array}\right\} e^{i(m t-\kappa x)}
$$

ここで, II, III 面間の距離を $d$, II 面での位相を $e^{i(\omega t-\kappa x)}$ とすれば， III 面での位相は $e^{i[\omega t-\kappa(x+d)\}}={ }^{-i \kappa d} \cdot e^{i(\omega t-\kappa x)}$ となるので $e^{-i \kappa d}=a-b i$ とおいた． II 面上の節点に関 する運動方程式を考えているので，節点力は面上の節 点についてだけ必要であり，算式は次のようになる。

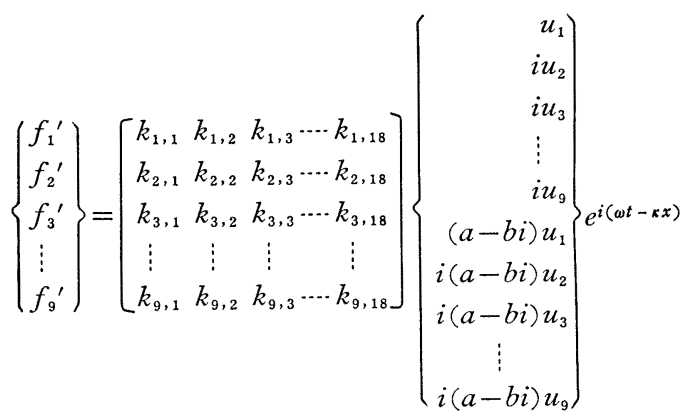

ただし， $f_{1}^{\prime} \sim f_{9}{ }^{\prime}$ は要素の節点力ベルトル成分のうち II 面上の節点に対応寸る部分, $k_{1,1} \sim k_{9,18}$ は要素の剛性又 トリックス成分のらち必要な部分を表わす.このマトリ ックス算式を実数部分からなる節点変位ベクトルで表わ せるように書きかえる.すなわち

$$
\left\{\begin{array}{c}
f_{1}^{\prime} \\
f_{2}^{\prime} \\
f_{3}^{\prime} \\
\vdots \\
f_{9}^{\prime}
\end{array}\right\}=\left[\begin{array}{ccccc}
k_{1,1}{ }^{\prime} & k_{1,2} & \cdots & k_{1,9}{ }^{\prime} \\
k_{2,1} & k_{2,2} & \cdots & k_{2,9^{\prime}} \\
k_{3,1} & k_{3,2}{ }^{\prime} & \cdots & k_{3,9^{\prime}} \\
\vdots & \vdots & & \vdots \\
k_{9,1} & k_{9,2} & \cdots & k_{9,9^{\prime}}
\end{array}\right]\left\{\begin{array}{c}
u_{1} \\
u_{2} \\
u_{3} \\
\vdots \\
u_{9}
\end{array}\right\} e^{i(\omega t-\kappa x)}
$$

ここでは剛性マトリックスの各成分は複素数であり, 元 の剛性マトリックス成分との関係は次のようである.

$$
\left.\begin{array}{c}
k_{1,1}{ }^{\prime}=k_{1,1}+(a-b i) k_{1,10} \\
k_{1,2}{ }^{\prime}=i k_{1,2}+i(a-b i) k_{1,11}
\end{array}\right\}
$$

まったく同様のことを対応する I , II 面間の要素につ いて行えば, 要素の剛性マトリックスは同一で下半分の みが必要となる.

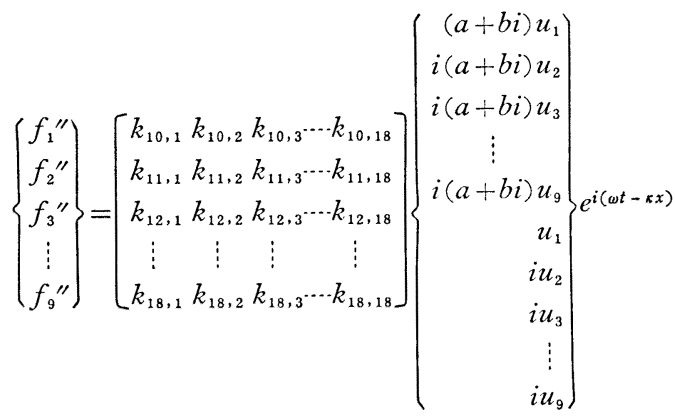

(6)

ただし， $f_{1}^{\prime \prime} \sim f_{9}^{\prime \prime}$ は要素の節点カベクトル成分のうち II 面上の節点汇対応する部分, $k_{10,1} \sim k_{18,18}$ は要素の剛性 マトリックス成分のらち必要な部分を表わす. 式 (4) と 同様に整理すると，両方の要素からの寄与を考虑した節 点力は両者の和

$$
\left\{\begin{array}{c}
f_{1} \\
f_{2} \\
f_{3} \\
\vdots \\
f_{9}
\end{array}\right\}=\left\{\begin{array}{c}
f_{1}^{\prime} \\
f_{2}^{\prime} \\
f_{3}^{\prime} \\
\vdots \\
f_{9}^{\prime}
\end{array}\right\}+\left\{\begin{array}{c}
f_{1}^{\prime \prime} \\
f_{2}^{\prime \prime} \\
f_{3}^{\prime \prime} \\
\vdots \\
f_{9}^{\prime \prime}
\end{array}\right\}
$$

となり，結局剛性マトリックスも加算されて次のように 表わされる.

$$
\left\{\begin{array}{c}
f_{1} \\
f_{2} \\
f_{3} \\
\vdots \\
f_{9}
\end{array}\right\}=\left[\begin{array}{cccc}
K_{1,1} & K_{1,2} & \cdots & K_{1,9} \\
K_{2,1} & K_{2,2} & \cdots & K_{2,9} \\
K_{3,1} & K_{3,2} & \cdots & K_{3,9} \\
\vdots & \vdots & & \vdots \\
K_{9,1} & K_{9,2} & \cdots & K_{9,9}
\end{array}\right]\left(\begin{array}{c}
u_{1} \\
u_{2} \\
u_{3} \\
\vdots \\
u_{9}
\end{array}\right\} e^{i(\omega t-\kappa x)}
$$

ここで, $f_{1} \sim f_{9}$ は正面上で両側の 要素からの寄与を考 慮した節点力ベクトルの成分, $K_{1,1} \sim K_{9,9}$ は新しい剛性 マトリックスの成分で元の剛性マトリックス成分との関 係注

$$
\begin{aligned}
& K_{1,1}=k_{1,1}+(a-b i) k_{1,10}+(a+b i) k_{10,1}+k_{10,10} \\
& K_{1,2}=i k_{1,2}+i(a-b i) k_{1,11}+i(a+b i) k_{10,2}+i k_{10,11} \\
& K_{1,3}=i k_{1,3}+i(a-b i) k_{1,12}+i(a+b i) k_{10,3}+i k_{10,12}
\end{aligned}
$$

である.

式 (8) は面上だけの節点変位と節点力の関係を表わ しており，実質的に 2 次元問題に帰着したことになる. この剛性マトリックスは, $1,4,7$ 行がすべて実数，その 
ほかの行はすべて純虚数であり，これは節点変位成分に 対応する節点力成分が同位相であることを示すもので， 弾性範囲で考えているため当然の結果である. なお，実 際にこの剛性マトリックスの成分がそらなることは, 元 の剛性マトリックスにおける三角柱要素の対称性から容 易に知られるが，付録 B にゆずる.

まったく同様の過程を質量マトリックスについても行 い,さらに全体の岡性マトリックス, 全体の質量マトリ ックスを組み立てた後の運動方程式を個別に書き表わせ ば次のようになる。

$$
\begin{aligned}
& K_{1,1}{ }^{\prime} u_{1}{ }^{\prime}+K_{1,2}{ }^{\prime} u_{2}{ }^{\prime}+\cdots \\
& \quad-\omega^{2}\left(M_{1,1}{ }^{\prime} u_{1}^{\prime}+M_{1,2}{ }^{\prime} u_{2}{ }^{\prime}+\cdots\right)=0 \\
& i\left\{K_{2,1}{ }^{\prime} u_{1}^{\prime}+K_{2,2}{ }^{\prime} u_{2}{ }^{\prime}+\cdots\right. \\
& \left.\quad-\omega^{2}\left(M_{2,1}{ }^{\prime} u_{1}^{\prime}+M_{2,2}{ }^{\prime} u_{2}{ }^{\prime}+\cdots\right)\right\}=0 \\
& i\left\{K_{3,1}{ }^{\prime} u_{1}^{\prime}+K_{3,2}{ }^{\prime} u_{2}{ }^{\prime}+\cdots\right. \\
& \left.-\omega^{2}\left(M_{3,1}{ }^{\prime} u_{1}^{\prime}+M_{3,2}{ }^{\prime} u_{2}{ }^{\prime}+\cdots\right)\right\}=0
\end{aligned}
$$

ただし， $K_{1,1}{ }^{\prime} \sim, M_{1,1}{ }^{\prime} \sim, u_{1}^{\prime}$ 〜 はそれぞれ全体の剛性 マトリックス，全体の質量マトリックスおよび全体の節 点変位ベクトルの成分であり, 振動項 $e^{i(\omega t-\kappa x)}$ は省略 した.

式（10）においては $i$ を省略できるので, 結局実数係 数の固有值問題に帰着したことになる.すなわち, 有限 要素法の定式化の過程 で変数分離した Aalami の手法 に対し，定式化されたものに変数分離を用いた点が異な るが，最終的には同一の結果が得られた．この固有值問 題をたとえげべき乗法などで解けば，固有值から位相速 度が，固有ベクトルから節点変位が，さらに節点変位か ら応力が計算できる.

\section{1 次要素と 2 次要素の比較}

ここに述べた手法の妥当性を確かめるために，Lamb により㛜密解が与えられている無限板中の弾性波に対し て同法を適用してみた。座標，分割（ただし $z$ 方向に 5 列に分割した場合）は図一2の通りである。 $x$ 軸を波の 進行方向， $z$ 軸を板厚方向とすれば現象は $y$ 方向に同一 であり， $z=0$ の面に対して対称（縦波の場合）である から，図のように一部分だけを分割すればよい，境界条 件は $z=0$ の面上で $w=0$ である. 材質は鋼を想定して ヤング率 $E=2.1 \times 10^{12} \mathrm{dyne} / \mathrm{cm}^{2}$, ポアソン比 $\nu=0.29$, 密度 $\rho=7.85 \mathrm{gr} / \mathrm{cm}^{3}$ を用いた。

図一3 注縦波の低次 5 分枝に対する無次元化された位 相速度曲線である. ここで $H$ は板厚の半分, $A$ は波 長, $C$ は位相速度, $C_{L}$ は波長が無限大の時の位相速度 を表わす，以下の図では，実線が Lamb による厳密解

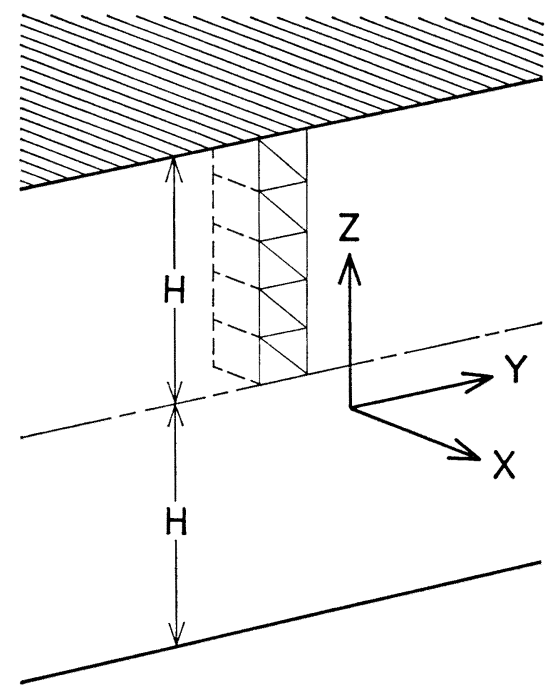

图一2 無限板の分割

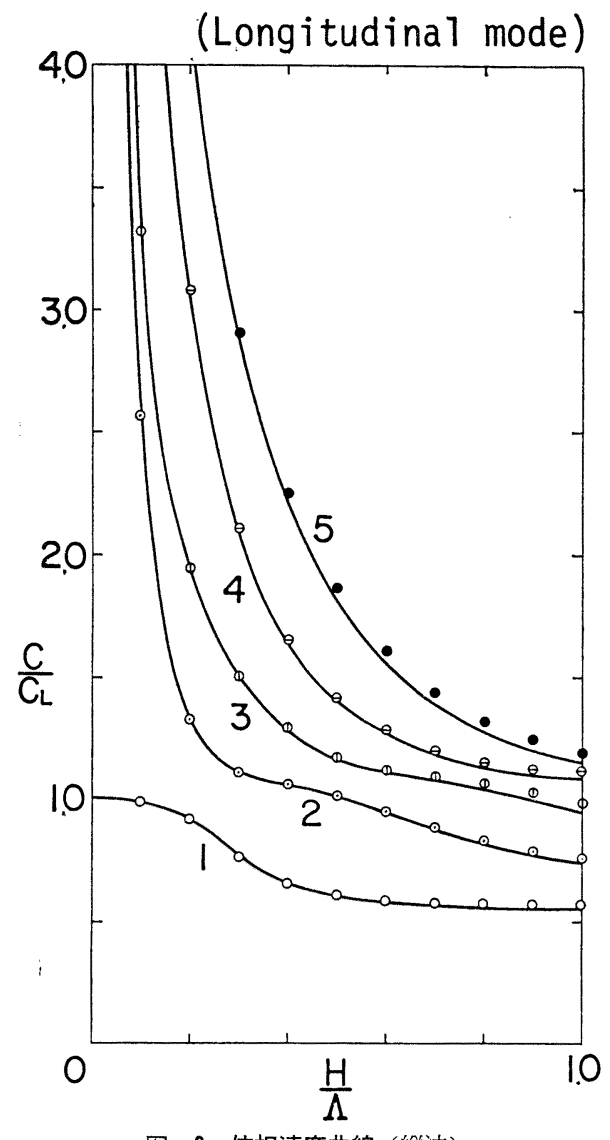

図一－位相速度曲線（紛波）

を，種々の丸印は本法による計算值を，数字は分枝の番 号を表わしている，理論值と計算值はよく一致してお り，図示された範囲での相対誤差の最大は $4.45 \%$ であ る. 理論值とのずれは一般に高次の分枝となるにしたが 
いまた H/A が大きくなるにしたがって顕著になるの が認められる，後に図示されるように，この理由はおも に要素内の変位の変動がより大となるためと考えられ，

予想された結果と言える.

Aalami は正方形断面を対象とし，位相速度と变位分 布の概形のみを扱ったため，1 次要素を用いて全断面内 を 100 個の要素に分割する（著者の場合に換算すると一 方向に 3.5 節点を設ける) ことにより, 妥当な結果を得 たとしている. 一方, 著者は変位および応力の分布をも 問題としたために, 以下に示すように 1 次要素では不十 分で, 2 次要素を用いかつ節点数も Aalami の 6 倍程度 は必要であるとの結論になった. 本法を用いて位相速 度, 变位, 応力を求めると一般に後者ほど精度が悪くな るため, 両者の結論がそれぞれ異なるのは当然と言え る.

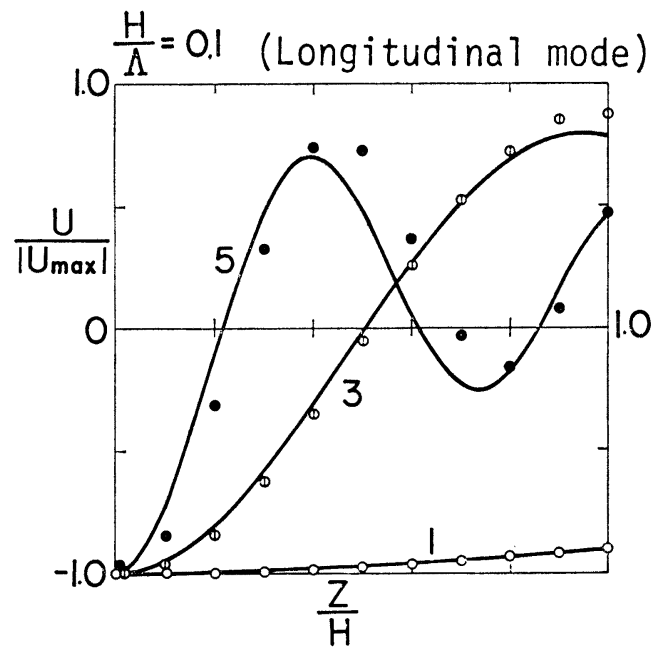

(a) 1 次要素, 11 節点

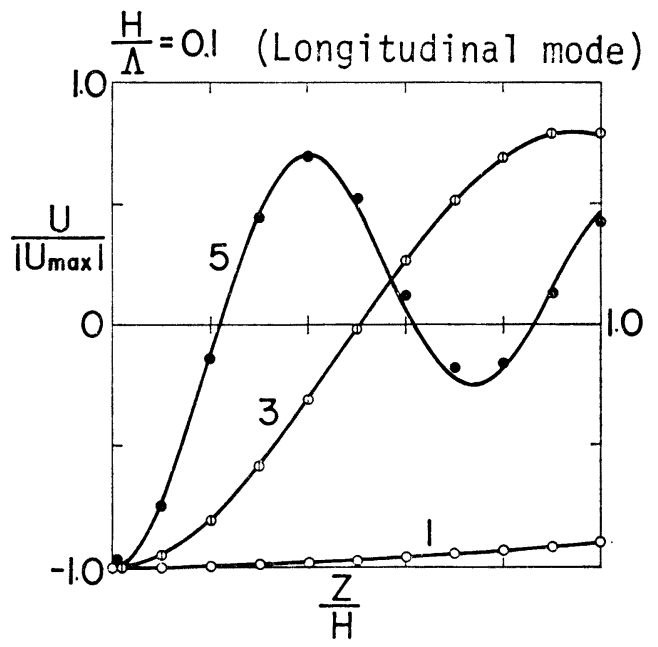

(c) 2 次要素, 11 節点
表一1 相位速度の誤差（\%）

\begin{tabular}{|c|c|c|c|c|c|c|c|c|}
\hline & & & 11 & 節 & 点 & 21 & 節 & 点 \\
\hline 1 & 次 要 & 萦 & & 4.45 & & & 1.27 & \\
\hline 2 & 次 要 & 素 & & 1.75 & & & 0.54 & \\
\hline
\end{tabular}

表一2 計 算 時 間（秒）

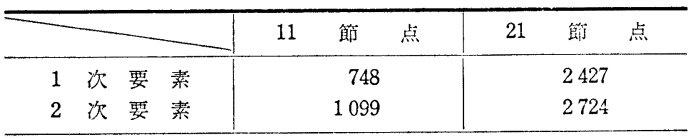

表一1 1 次要素と 2 次要素を用いた場合， $z$ 軸に沿 った節点数が 11 と 21 の場合の精度を比較するため に, 図一3 と同じ範囲で位相速度の相対誤差の最大值を 示したものである.よく知られているょうに，同一節点 数では明らかに 2 次要素の方が優れていることがわか る.なお，次数の異なる要素同士の精度を比較するため

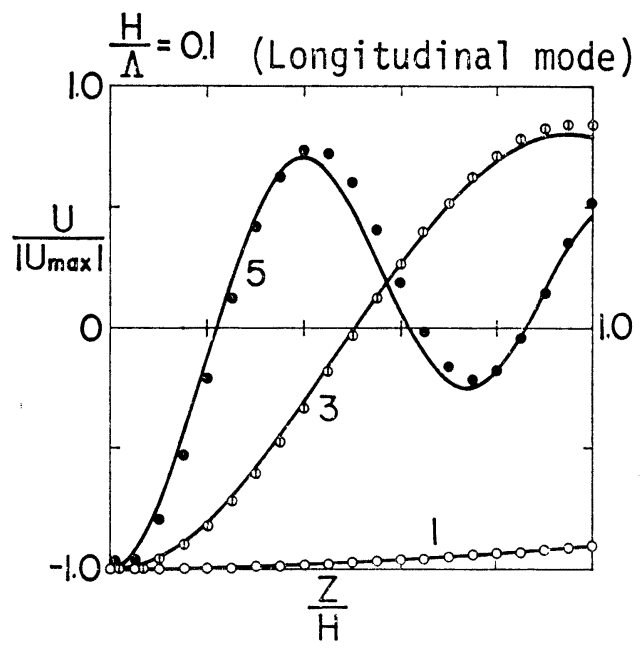

(b) 1 次嬖素, 21 節点

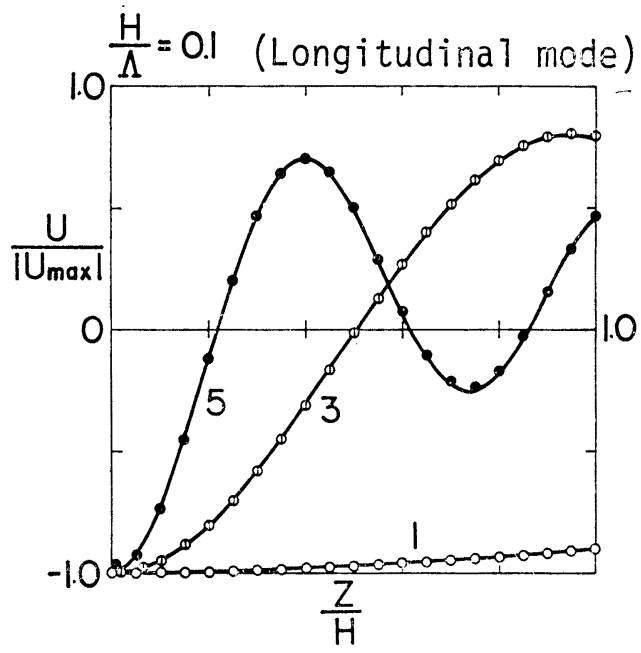

(d) 2 次要素, 21 節点 
には同一要素数ではなくて同一節点数, すなわち, 同一 自由度にすべきことは論をまたないであろう。

表一2 は $H / A$ の 10 個の值に関しそれぞれ第 5 分枝 まで，変位㧍よび応力成分すべてを計算した際の所要時 間，いわゆる CPU TIME である. まったく同形の要 素で分割し要素の計算を 1 個だけで済ませているため, 計算時間の差はおもに固有值および固有ベクトル計算の 際の, 心゙き乗法による収束時間に由来していると考えて さしつかえない．次節で示すように，ここで用いた 2 次 要素はまわりくどい計算方法を採用しているため，いず れの場合も 300 秒ほど計算時間が多くなっている. した がってまったく対等の比較とは言えないが，少ない時間 で精度を上げるためには，1次要素で節点数を増やすよ りも2 次要素を用いる方がよいことは明膫に現われてい る.

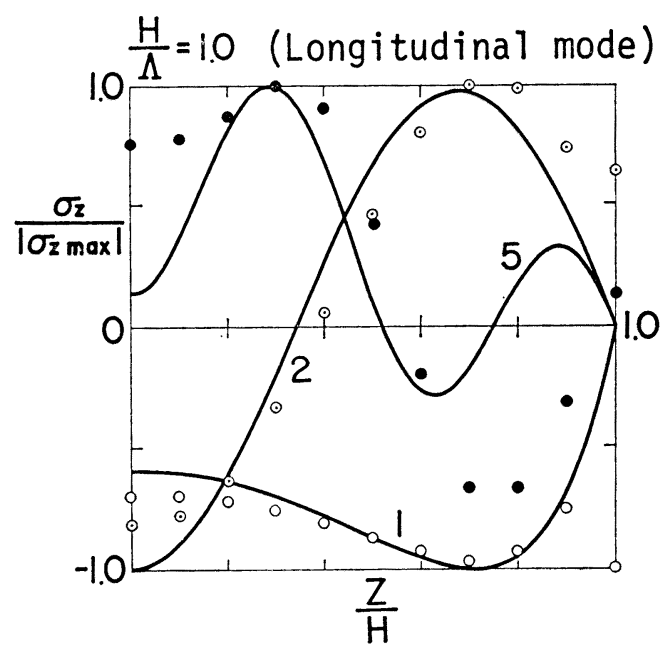

(a) 1 次要素, 11 節点

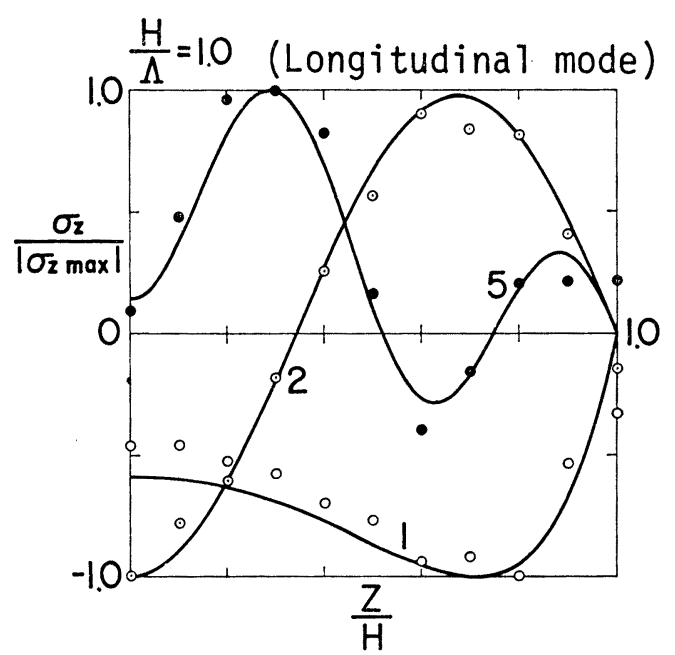

(c) 2 次要素, 11 節点
図一4 は，同様の比較を $H / A=0.1$ の時の变位成分 $u$ の振幅分布 $U$ に関して行ったものである．位相速度の 場合とは逆に, 2 次要素の 11 節点の方が 1 次要素の 21 節点よりもよい結果を与えていることが注目される.な お, 以後の変位および応力の振幅分布図では, 図の煩雑 さを避けるため適宜 $3 \sim 5$ 分枝を取り上げる.

図一5 は， $H / \Lambda=1.0$ の時の応力成分 $\sigma_{z}$ の振幅分布 を示したものである. 理論上 $\sigma_{z}=0$ とななるべき板の表 面 $(z / H=1.0)$ での值は誤差の目安と考えられ, 1 次要 素ではかなり精度が落ちることが解る. また，2 次要素 で 11 節点の結果は 1 次要素で 21 節点のものに匹敵す る精度と言えるが, 第 5 分枝までの応力分布を表わすに は 11 節点では不十分であることも明らかであろう.な お, 応力值は節点を共有するすべての要素の算術平均を 用いたが，それでも 2 次要素による值には若干の振動が

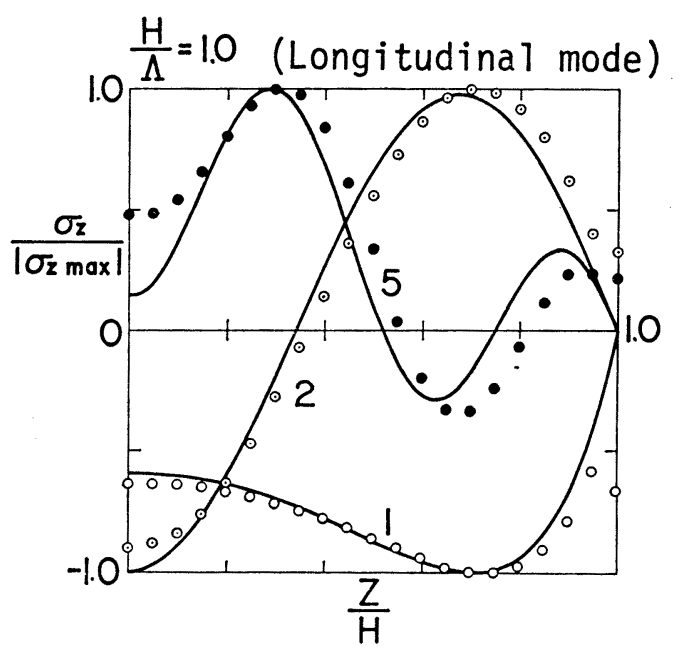

(b) 1 次要素, 21 節点

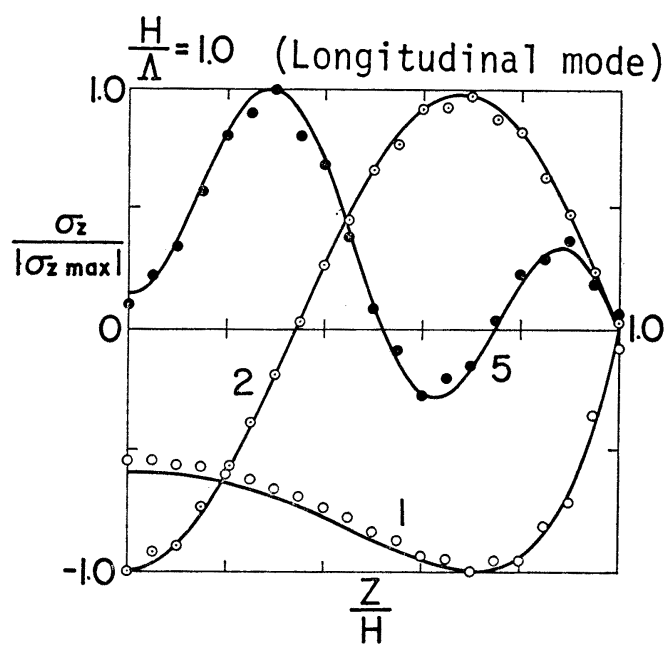

(d) 2 次要素, 21 節点

図一5 応力成分 $\sigma_{z}$ の比較 (䌦波) 
認められる。

以上のように精度と計算時閒を比較した結果, 応力 分布などを問題とする場合は 1 次要素では不十分であ り, 2 次要素を用い節点数も一方向に 21 程度は必要 であることが解った。

\section{2 次要素による計算例}

ここで用いた 2 次要素は直接 18 節点の三角柱要素 として計算せずに, プログラミングを簡単にするため 図一6 のような 10 節点の四面体要素を 3 個組み合わ せた.この組み合わせ方は図一7に示すように 6 種類 あるのですべての相加平均を用いたが，計算時間の面 からは得策でない. なお, 四面体要素の諸マトリック

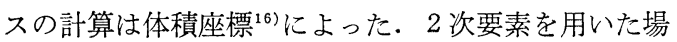
合の運動方程式の 2 次元化は 1 次要素を用いた場合と 同様であり，中間点の位相を考慮する必要があること と, 全体的にマトリックス成分が増えて煩雑になるこ と以外は特に目新しいことはない.

図一8 は, 変位および応力成分のうち 図一 4,5 に示 したもの以外の振幅分布を $H / \Lambda=0.1$ または $H / A=$ 1.0 に関して示したものである. 理論值と計算值は全 体を通じきわめてよく一致しており，わずかに $\tau_{z x}$ の 第 5 分枝で若干のずれと振動が見られるだけである.

まったく同様の計算を曲げ波 (Flexural wave) に ついても行った，無限板の場合は，境界条件を $z=0$ の面上で $u=0$ とおくことにより曲げ波が得られる. 図一9 は位相速度曲線であり, 非常に精度のよいこと がわかる.ちなみに，この範囲での相対誤差の最大は $0.55 \%$ であり, 縦波の場合（表一1）と似た值を示し ている.

図一10 は, 曲げ波の変位および応力成分の振幅分

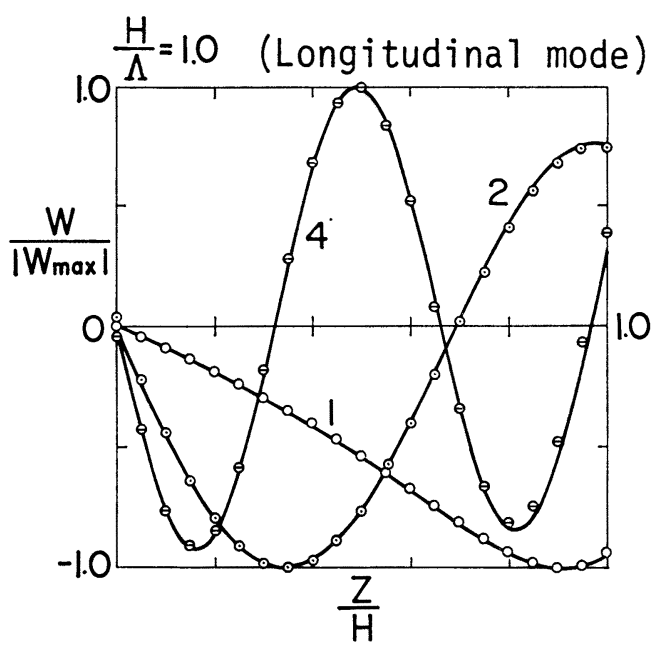

(a) 変位成分 $W$
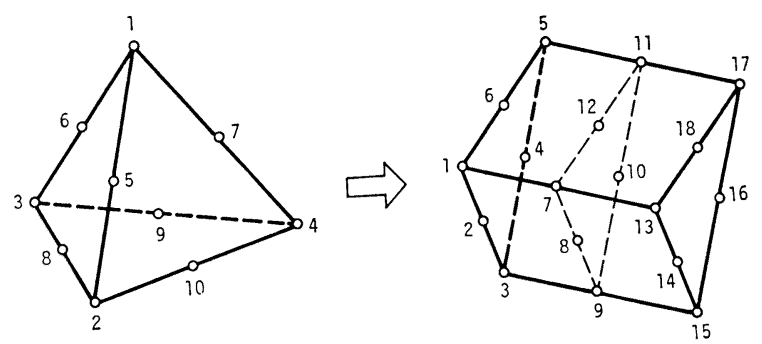

図一6 四面体要素と三角柱要素
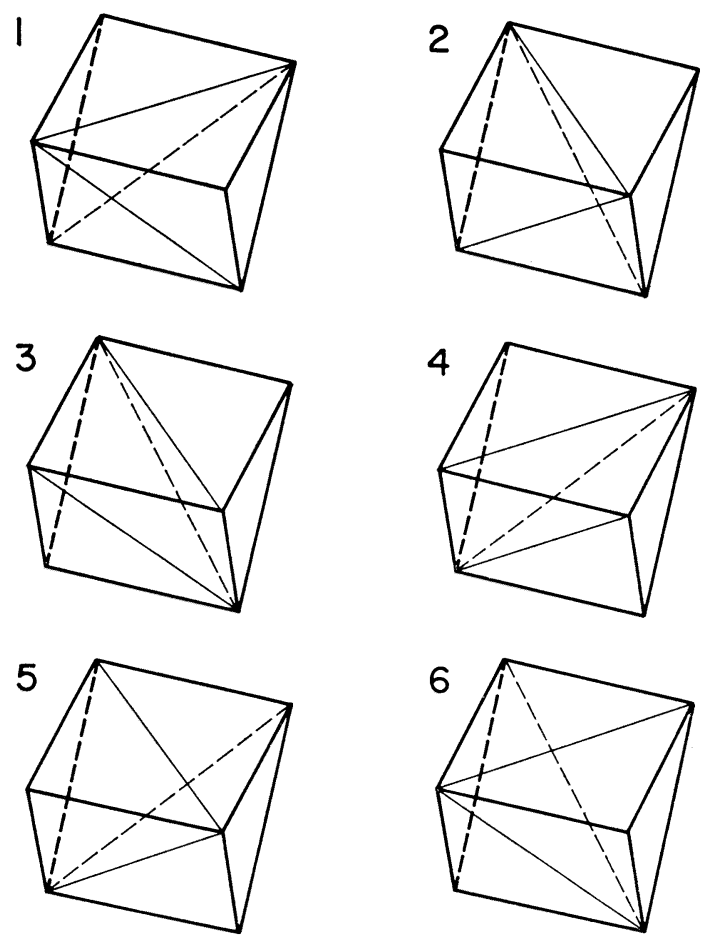

図一7 組み合わせのすべて

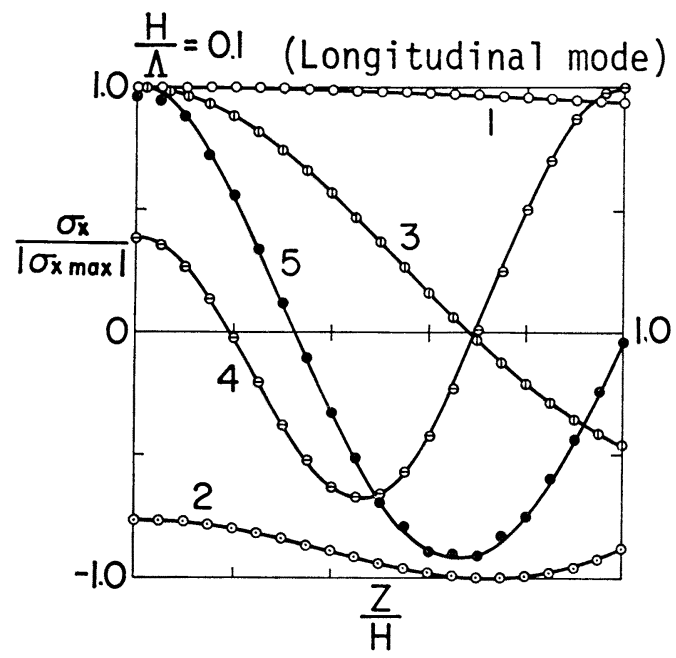

(b) 応力成分 $\sigma_{\boldsymbol{x}}$ 


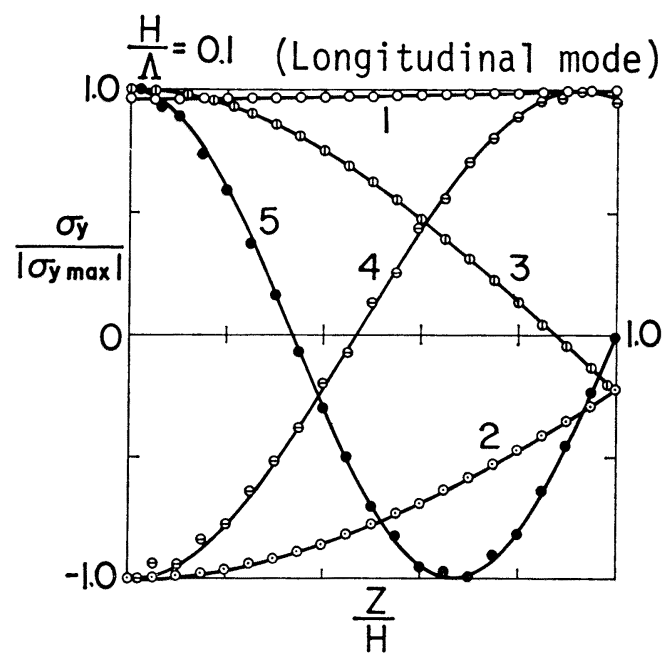

(c) 応力成分 $\sigma_{y}$

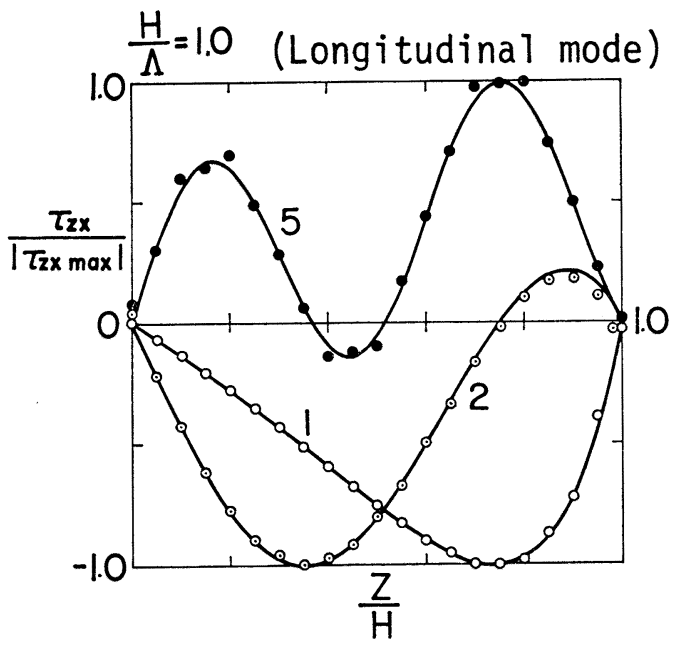

(d) 応力成分 $\tau_{z x}$

図一8 変位, 応力の振幅分布（縱波）

布である. 全体的にきわめてよい結果が得られており， ただ $1 つ \tau_{z x}$ の第 3 分枝だけが例外で 理論值とかけ離 れ大きく振動している. $W$ および $\sigma_{z}$ からも推測できる ように, $H / A=1.0$ の時の第 3 分枝は偶然にも特別な場 合になっており, 実際に $\tau_{z x}$ の值を他の応力成分値と比

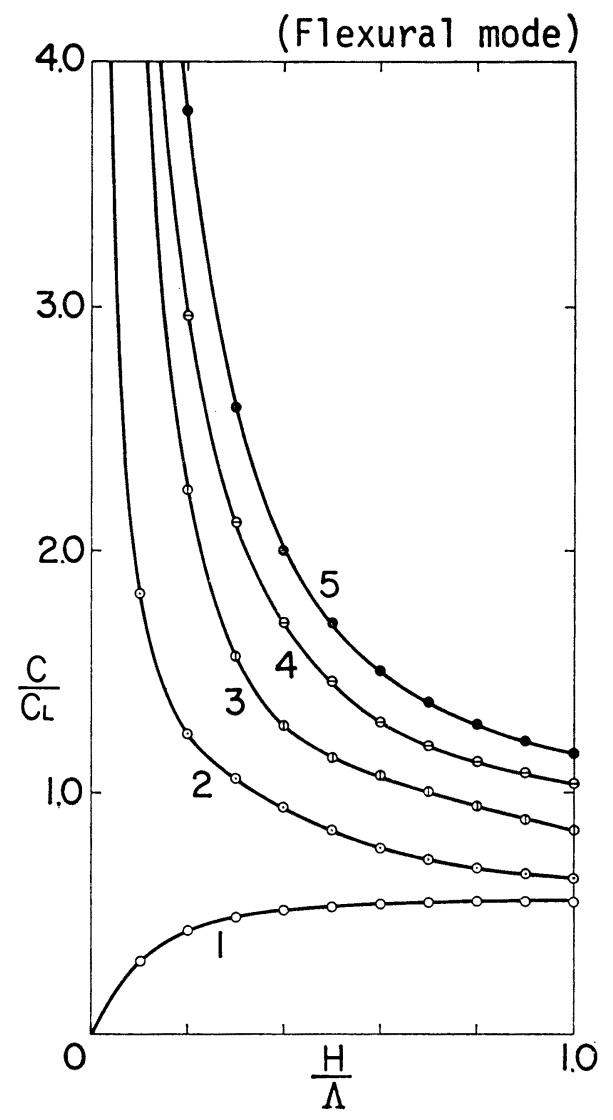

図一9 位相速度曲線（曲げ波）

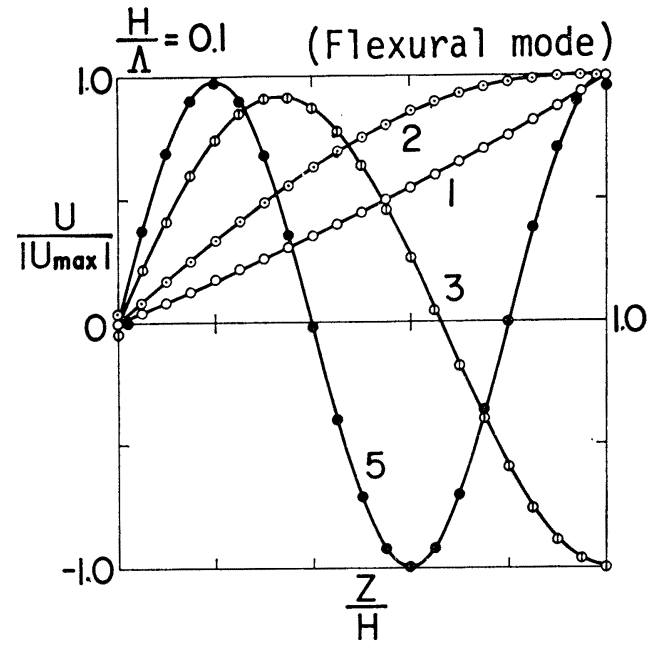

(a) 変位成分 $U$

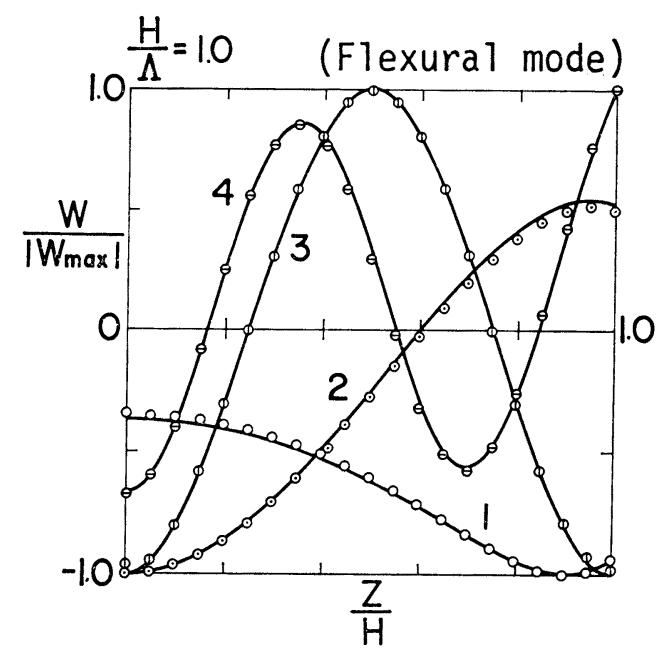

(b) 変位成分 $W$ 


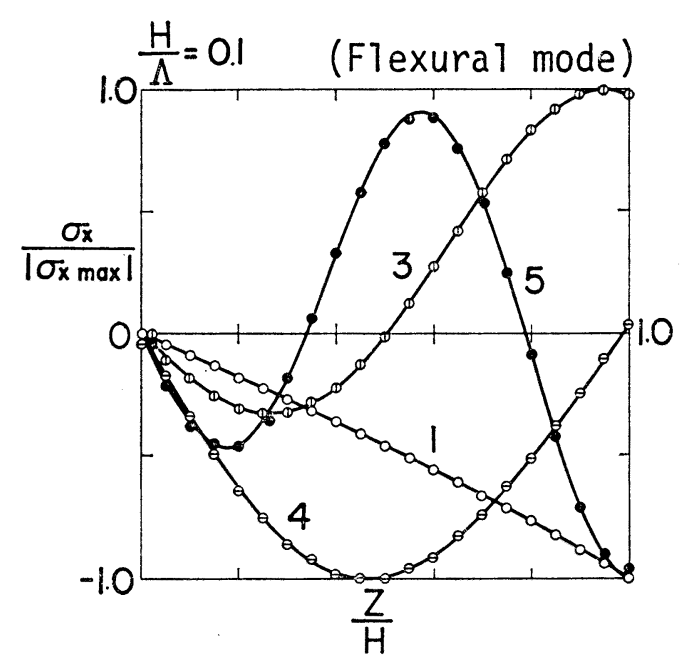

(c) 応力成分 $\sigma_{x}$

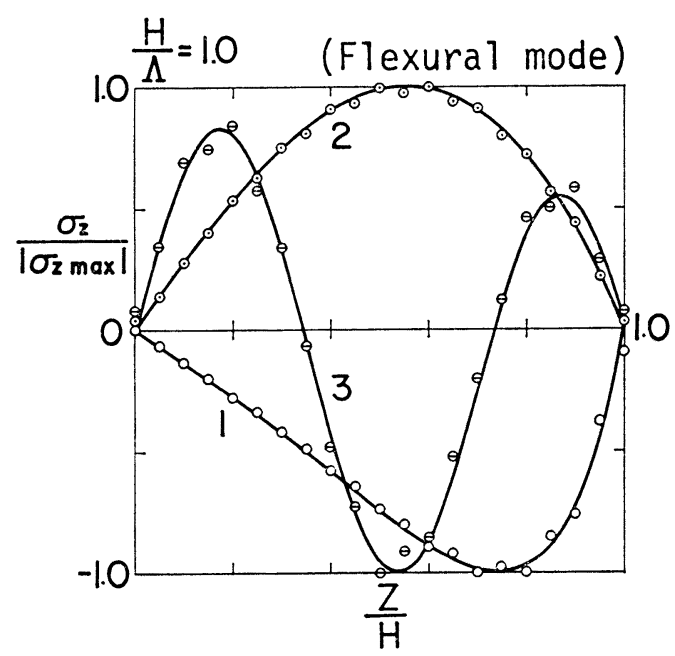

(e) 応力成分 $\sigma_{z}$

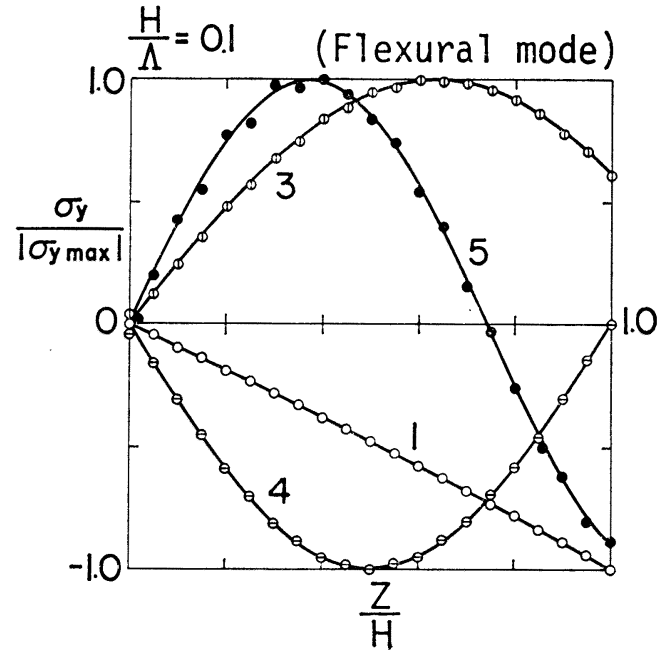

(d) 応力成分 $\sigma_{y}$

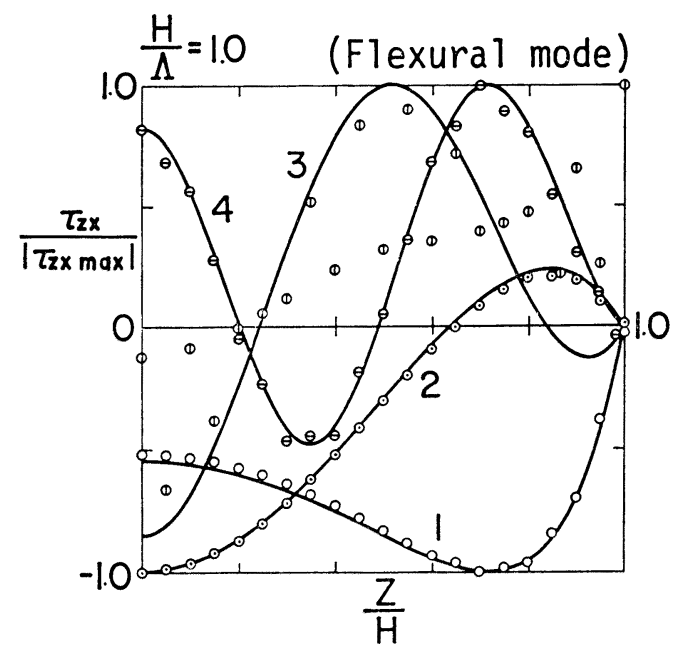

(f) 芯力成分 $\tau_{z x}$

図-10 変位, 応力の振幅分布（曲げ波）

較すると $1 / 100$ 程度である.すなわち, 図では $\left|\tau_{\boldsymbol{z} x}, \mathrm{max}\right|$ で割って無次元化したために誤差の部分を不必要に拡大 した訳で, 変位法により応力を求める場合 0 に近い值に 誤差が多くなることはやむを得ないと言えよう.

以上の上うに, Lamb の解を対象とし H/A が 0.1 か ら 1.0 の範囲で低次の 5 分枝程度を問題にする限りは, 2 次要素を用い $z$ 朝方向に 21 節点を設ければきわめて 良好な結果が得られることが示された。もちろんより高 次の分枝を問題にする場合は，さらに節点数を增やしよ り高次の要素を用いる必要が生じると思われるが，一般 的に重要なのは低次の 5 分枝程度であることから本稿の の範囲外とした.

\section{5. あとがき}

有限要素法により任意の断面形状をした無限に長い棒 中の弾性波を解析する Aalami の手法は, 独立になされ た著者の研究によりその妥当性が裏付けられた。本法で は一般に位相速度, 变位, 応力と順次精度が悪くなるた め, 位相速度と変位分布の概形のみを考察した Aalami が1次要素で満足したのは自然であると思われる.しか しながら, 無限板中の弾性波を対象として厳密解と本法 による計算值を比較した結果, 応力分布を問題とするた めには少なくとも2 次要素の使用が必要であり, 低次の 5 分枝程度を扱うためには 1 つの軸に沿って 21 節点程 度を用いれば十分であることが解った。 
なお，実際に複雑な形状をした断面の棒に適用する場 合は，節点数が非常に多くなりコンピュータの内部記憶 容量では処理できなくなるためさらに若干の工夫が必要 である、また四面体要素を組み合わせたのでは計算時間 が長くなるので, 三角柱の 2 次要素を直接計算するのが 望ましい.これらの点に関しては別の機会に稿を改めて 述べたいと考えている.

本研究の遂行に必要な計算は東北工業大学計算センタ 一の TOSBAC-3400/41 により，また同センターの諸氏 には計算上有益なご助言をいただいた。記して謝意を表 わす次第である.

\section{付録 $\mathbf{A}$}

まず，棒の表面に平面の部分があるとして，その平面 に垂直に $z$ 軸を定める.ここで位相差を表わすために末 知数 $\alpha, \beta, \gamma, \delta$ を用い变位成分を次のように仮定すると

$$
\begin{aligned}
u & =\quad U(y, z) e^{i(\omega t-\kappa x)} \\
v & =(\alpha+\beta i) V(y, z) e^{i(\omega t-\kappa x)} \\
w & =(\gamma+\delta i) W(y, z) e^{i(\omega t-\kappa x)}
\end{aligned}
$$

せん断応力は

$$
\begin{aligned}
\tau_{z x} & =G\left(\frac{\partial u}{\partial z}+\frac{\partial w}{\partial x}\right) \\
& =G\left\{\frac{\partial U}{\partial z}+(\hat{o}-\gamma i) \kappa W\right\} e^{i(\omega t-\kappa x)} \\
\tau_{y z} & =G\left(\frac{\partial w}{\partial y}+\frac{\partial v}{\partial z}\right) \\
& =G\left\{(\gamma+\delta i) \frac{\partial W}{\partial y}+(\alpha+\beta i) \frac{\partial V}{\partial z}\right\} e^{i(\omega t-\kappa x)}
\end{aligned}
$$

と六る.ここで $G$ 流せん断弾性係数. 注目する表面で はこれらが恒等的に0でなければならないから

$$
\begin{aligned}
& \text { rik } W=0 \\
& \alpha \frac{\partial V}{\partial z}+\gamma \frac{\partial W}{\partial y}=0
\end{aligned}
$$

ここでんは 0 でなく, $W$ も表面上で常に 0 とは限らな いので $\gamma=0$, 同様に $\partial V / \partial z$ も一般には 0 でないから $c=0$, したがって式 (1) の仮定は妥当であることが知れ る. なお一般には棒の表面に平面の部分があるとは限ら

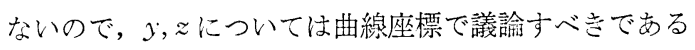
が，その場合も式が複雑になるだけで考え方は同様であ る.

\section{付録 B}

要素の剛性マトリックス成分 $k_{i, j}$ は式 (3) からもわ かるように, 要素の節点変位ベクトル成分 $u_{j}$ が 1 で他 はすべて0の状態にするための要素の節点力ベクトル成 分 $f_{i}$ を表わしている. まず $i, j$ ともに $1,4,7$ すなわ
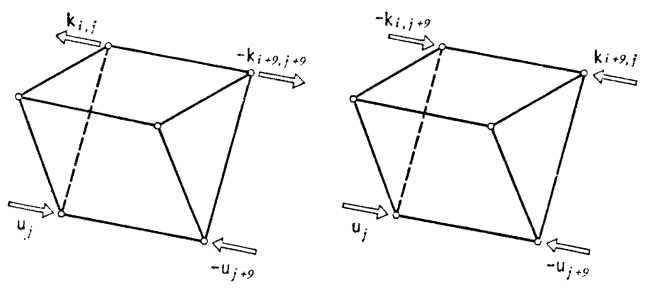

(1) $k_{i, j}=k_{i+9, j+9}$ (2) $k_{i, j+9}=k_{i+9}, j$

(a) $i=1,4,7 ; j=1,4,7$
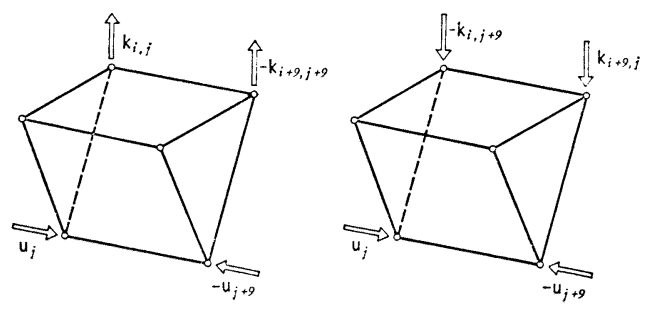

(1) $k_{i, j}=-k_{i+9, j+9}$ (2) $k_{i+9, j}=-k_{i, j+9}$

(b) $i \neq 1,4,7 ; j=1,4,7$
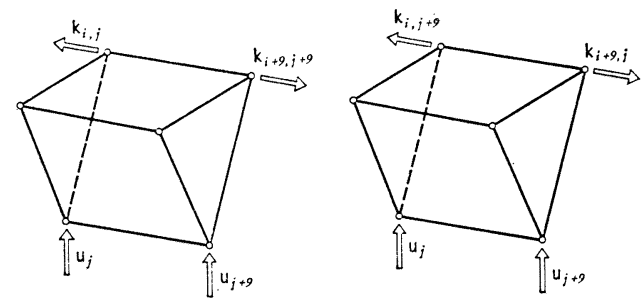

(1) $k_{i, j}=-k_{i+9, j+9}$ (2) $k_{i+9, j}=-k_{i, j+9}$

(c) $i=1,4,7 ; j \neq 1,4,7$
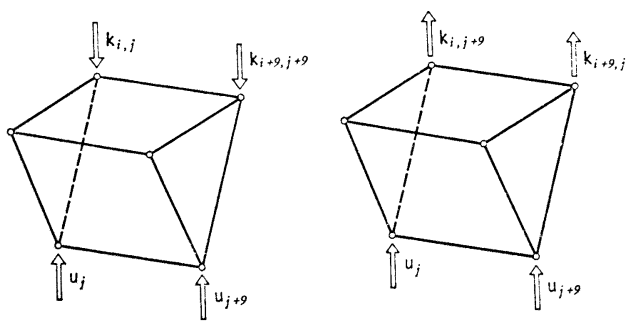

(1) $k_{i, j}=k_{i+9, j+9}$ (2) $k_{i, j+9}=k_{i+9, j}$

(d) $i \neq 1,4,7 ; j \neq 1,4,7$

\section{図一11 剛性マトリックス成分の相互関係}

ち $x$ 軸方向成分を表わす場合を考えると，図一11の(a) (1)で $u_{j}$ のみが 1 の時の $f_{i}$ が $k_{i}, j$ であり, 三角柱 要素の対称性から $u_{j+9}$ のみが -1 の時の $-f_{i+9}$ は $-k_{i+9, j+9}$ となり, したがって

$$
k_{i, j}=k_{i+9, j+9}
$$

が知れる. 同栐に (a) (2)では $u_{j}$ のみが1の時の $f_{i+y}$ は $k_{i+9, j}$ であり, $u_{j+9}$ が -1 の時の $-f_{i}$ は $-k_{i, j+9}$ となり,

$$
k_{i, j+9}=k_{i+9, j}
$$

が知れる。 
以下 (b), (c), (d) に関してもまったく同様であり， その結果式 (9) でそれぞれ加え合わせる 4 個の成分はそ の中の 2 個ずつが等しいかまたは異付号であるため，結 局は実数部分または虚数部分が消えることになる.

\section{参 考 文 献}

1) Kolsky, H. : Stress Waves in Solids, Dover Publications Inc., New York, 1963.

2) Ewing, W.M., Jardetzky, W.S. and Press, F. : Elastic Waves in Layered Media, McGraw-Hill Book Company Inc., New York, 1957.

3) Akita, H. : Stress Distribution of Elastic Waves in an Infinite Plate and a Cylindrical Bar, Proc. 21st Japan National Congress for Applied Mechanics, Vol. 21, pp. 93 99, 1971.

4) Mindlin, R.D. and Fox, E.A. : Vibrations and Waves in Elastic Bars of Rectangular Cross Section, J. Applied Mechanics, Vol. 27, pp. 152 158, 1960.

5) Medick, M.A. : One-Dimensional Theories of Wave Propagation and Vibrations in Elastic Bars of Rectangular Cross Section, J. Applied Mechanics, Vol. 33, pp. 489 495, 1966.

6) Nigro, N.J. : Steady-State Wave Propagation in Infinite Bars of Noncircular Cross Section, J. Acoustical Soc. America, Vol. 40, pp. 1501 1508, 1966.

7) Fraser, W.B. : Stress Wave Propagation in Rectangular Bars, Int. J. Solids and Structures, Vol. 5, pp. 379 397, 1969.
8) Booker, R.E. and Fraser, W.B. : Dispersion of Elastic Waves in a Triangular Bar, J. Sound and Vibration, Vol. 18, No. 2, pp. 261 269, 1971.

9） O.C. ツィエンキーヴィッツ著, 吉識雅夫・山田嘉昭監訳: 基礎工学におけるマトリックス有限要素法, 培風館, 1975 .

10) Aalami, B. : Waves in Prismatic Guides of Arbitrary Cross Section, J. Applied Mechanics, Vol. 40, pp. 1067 1072, 1973.

11) 秋田 宏：任意断面棒中の弾性波の応力分布について, 昭和 46 年度東北支部技術研究発表会溝 演 概 要 pp. 205 $\sim 206,1972$.

12) Akita, H. : An Elastic Wave Solved by the Use of the Finite-Element Method, Proc. 22nd Japan National Congress for Applied Mechanics, Vol. 22, pp. 137 142, 1972.

13）秋田 宏: 高次のモードを含めた Lamb 波の解析例, 昭 和 48 年度東北支部技術研究発表会僲滨概要, pp. 16 17, 1974.

14）秋田 宏: 2 次要素による Lamb 波の解析例, 土木学会 第 27 回年次学術講演会講演 概 要集 I, pp. 522 523, 1974.

15) Akita, H. : Numerical Analyses of Lamb's Waves with the Aid of Quadratic Elements, Proc. 24th Japan National Congress for Applied Mechanics, Vol. 24, pp. 219 226, 1974.

16） I. ホランド・K. ベル監修, 川井忠彦監訳：ホランド/へ 儿有限要素法, 朝倉幚店, 1972 .

(1976.7.15・受付) 